$\langle$ Review〉

\title{
Changing C-N Interactions in the Forest Floor under Chronic N Deposition: Implications for Forest $\mathrm{C}$ Sequestration
}

\author{
Park, Ji-Hyung \\ Division of Forest Resources. College of Forest \& Environmental Sciences, Kangwon National University, \\ Chuncheon 200-701, Korea
}

\begin{abstract}
Atmospheric $\mathrm{N}$ deposition has far-reaching impacts on forest ecosystems, including on-site impacts such as soil acidification, fertilization, and nutrient imbalances, and off-site environmental impacts such as nitrate leaching and nitrous oxide emission. Although chronic $\mathrm{N}$ deposition has been believed to lead to forest $\mathrm{N}$ saturation, recent evidence suggests that $\mathrm{N}$ retention capacity, particularly in the forest floor, can be surprisingly high even under high $\mathrm{N}$ deposition. This review aims to provide an overview of $\mathrm{N}$ retention processes in the forest floor and the implications of changing $\mathrm{C}-\mathrm{N}$ interactions for $\mathrm{C}$ sequestration. The fate of available $\mathrm{N}$ in forest soils has been explained by the competitive balance between tree roots, soil heterotrophs, and nitrifiers. However, high rates of $\mathrm{N}$ retention have been observed in numerous $\mathrm{N}$ addition experiments without noticeable increases in tree growth and soil respiration. Alternative hypotheses have been proposed to explain the gap between the input and loss of $\mathrm{N}$ in $\mathrm{N}$-enriched, $\mathrm{C}$-limited systems, including abiotic immobilization and mycorrhizal assimilation, both of which do not require additional $\mathrm{C}$ sources to incorporate $\mathrm{N}$ in soll $\mathrm{N}$ pools. Different fates of $\mathrm{N}$ in the forest floor have different implications for $\mathrm{C}$ sequestration. $\mathrm{N}$-induced tree growth can enhance $\mathrm{C}$ accumulation in tree biomass as observed across temperate regions. $C$ loss from forests can amount to or outweigh $\mathrm{C}$ gain in $\mathrm{N}$-saturated, declining forests, while another type of 'C-N decoupling' can have positive or neutral effects on soil $\mathrm{C}$ sequestration through hampered organic matter decomposition or abiotic $\mathrm{N}$ immobilization, respectively.
\end{abstract}

Key words: $\mathrm{C}$ sequestration, Forest ecosystem, Forest floor, $\mathrm{N}$ deposition, $\mathrm{N}$ retention, $\mathrm{N}$ saturation

\section{INTRODUCTION}

As a result of human alteration of the global $\mathrm{N}$ cycle through fossil fuel combustion, fertilizer application, and cultivation of $\mathrm{N}$ fixing crops, anthropogenic creation of reactive nitrogen $(\mathrm{Nr})$ was estimated at $187 \mathrm{Tg}\left(10^{12} \mathrm{~g}\right) \mathrm{N} \mathrm{yr}^{-1}$ in 2005 , far exceeding the natural level of terrestrial $\mathrm{N}$ fixation at $90 \sim 130 \mathrm{Tg} \mathrm{N} \mathrm{yr}^{-1}$ (Galloway et al. 1995, 2008, Vitousek et al. 1997). This human intervention in the global $\mathrm{N}$ cycle has serious potential ecological and environmental consequences, because increased $\mathrm{N}$ availability can affect all levels of ecological processes and organisms adapted to otherwise N-limited ecosystems (Vitousek and Howarth 1991). Elevated atmospheric $\mathrm{N}$ deposition to forests has been of particular concern due to adverse effects on the structure and function of forest ecosystems (Nihlgård 1985, Schulze 1989, McNulty et al. 1996), along with off-site environmental impacts including deterioration of downstream water quality (Stoddard 1994, Aber et al. 2003) and altered atmospheric fluxes of trace greenhouse gases such as nitrous oxide and methane (Steudler et al. 1989, Tietema et al. 1991, Matson et al. 2002).
Over the last couple of decades, concerns about these cascade effects of $\mathrm{N}$ deposition have led to initiation of many large research projects examining the interactions between $\mathrm{N}$ deposition and ecosystem processes in Europe (e.g., Tamm et al. 1995, Wright and van Breemen 1995, Wright and Rasmussen 1998, Giles 2005) and in North America (e.g., Kahl et al. 1993, Magill et al. 1996, Peterjohn et al. 1996, Pregitzer et al. 2004). One of the most surprising results from these studies has been the unexpected high rates of $\mathrm{N}$ retention in forests (Magill et al. 1997, Gundersen et al. 1998b, Nadelhoffer et al. 1999b), although high levels of atmospheric $\mathrm{N}$ inputs had long been believed to lead to forest $\mathrm{N}$ saturation, causing loss of $\mathrm{N}$ in excess of forest demand ( $\AA$ gren and Bosatta 1988, Aber et al. 1989). To explain the discrepancy between the $\mathrm{N}$ saturation hypothesis and the observed high rates of $\mathrm{N}$ retention in forests, alternative hypotheses have been proposed, including mycorrhizal assimilation (Aber et al. 1998) and abiotic immobilization (Dail et al. 2001).

The forest floor has been proposed as the primary sink for atmospheric $\mathrm{N}$ deposited in forests (Emmet et al. 1998, Currie et al. 1999, Currie and Nadelfoffer 1999, Nadelhoffer et al. 1999a, 2004). $\mathrm{N}$ addition experiments employing ${ }^{15} \mathrm{~N}$ tracers have shown higher

\footnotetext{
* Corresponding author; Phone: +82-33-250-8365, e-mail: jihyungpark@kangwon.ac.kr
} 
rates of $\mathrm{N}$ retention in soil organic horizons than in mineral soils (Tietema et al. 1998, Nadelhoffer et al. 1999a, 2004). Since increased inputs of $\mathrm{N}$ to forests with limited natural supply can lead to greater tree biomass accumulation per unit area, recent studies have suggested that $\mathrm{N}$-stimulated tree $\mathrm{C}$ accumulation might account for a substantial portion of missing $\mathrm{C}$ in temperate regions (Kauppi et al. 1992, Schimel 1995, Melillo 1996, Townsend et al. 1996). On the other hand, experiments conducted in relatively N-rich forests have shown that forests accumulating substantial amounts of deposited $\mathrm{N}$ in soil organic horizons can also accumulate higher total soil organic matter through reduced organic matter decomposition (Nohrstedt et al. 1989, Smolander et al. 1994, Magill and Aber 1998, Pregitzer et al. 2008). N-induced changes in soil organic matter accumulation have important implications for the global $\mathrm{C}$ cycle, because altered rates of organic matter decomposition can provide either positive or negative feedbacks to rising atmospheric $\mathrm{CO}_{2}$ concentrations and hence climatic warming (Nadelhoffer et al. 1999b, Magnani et al. 2007, Pregitzer et al. 2008).

The primary objective of this review is to provide an overview of the effects of atmospheric $\mathrm{N}$ deposition on microbial-detrital processes in the forest floor, with particular focus on changing C-N interactions under chronic $\mathrm{N}$ deposition and their implications for forest $\mathrm{C}$ sequestration. Specifically, I summarize recent advances in knowledge of $\mathrm{N}$ retention processes in the forest floor with particular reference to forest $\mathrm{C}$ sequestration to provide insights into the biogeochemical response of forest ecosystems to concurrent changes in atmospheric $\mathrm{CO}_{2}$ and $\mathrm{N}$ deposition.

\section{ATMOSPHERIC N DEPOSITION AND FOREST $\mathbf{N}$ SATURATION}

$\mathrm{N}$ enrichment or saturation of forests in response to long-term, high-level atmospheric $\mathrm{N}$ deposition can have cascades of ecologi$\mathrm{cal}$ and environmental consequences, ranging from changes in forest vitality through downstream water pollution to alteration of greenhouse gas fluxes. Major ecological and environmental impacts of elevated atmospheric $\mathrm{N}$ deposition, along with relevant references, are summarized in Table 2. Elevated atmospheric $\mathrm{N}$ inputs in otherwise N-limited forests can initially enhance forest productivity (Aber et al. 1989, Tamm et al. 1995). Over a prolonged period, however, chronic $\mathrm{N}$ deposition leads to a series of negative effects on a number of ecosystem processes.

Since the concept of nitrogen saturation was first introduced by Ingestad et al. in 1981 (Stud. For. Suec. 160: 61 71; re-cited from Aber 1992), numerous research projects have been conducted to investigate a range of ecological consequences of chronic $\mathrm{N}$ deposition and subsequent $\mathrm{N}$ enrichment or saturation of forests. Although the term ' $\mathrm{N}$ saturation' has been defined in several different ways (Table 1), it is now generally accepted that $\mathrm{N}$ saturation of an ecosystem is usually manifested by the long-term alleviation of $\mathrm{N}$ limitation on biological function and a subsequent decrease in the $\mathrm{N}$ retention capacity of the system (Gundersen 1991, Magill et al. 1997, Aber et al. 1998, 2003, Fenn et al. 1998).

$\mathrm{N}$ saturation has been hypothesized to progress through four successional stages (Aber et al. 1989). According to this model, major symptoms of $\mathrm{N}$ saturation emerge in stage 2 after positive responses of forests in stage 1 that occur when $\mathrm{N}$ limitation (stage 0 ) is alleviated and foliar $\mathrm{N}$ concentrations and tree production increase. In stage 3, chronic $\mathrm{N}$ deposition leads to forest decline following extraordinarily increased tree mortality.

Common to the majority of results from $\mathrm{N}$ saturation studies are temporary increases in $\mathrm{N}$ mineralization, continuous increases in nitrification, nitrate leaching, and foliar $\mathrm{N}$ content, and decreases in the ratios of $\mathrm{Ca}: \mathrm{Al}$ and $\mathrm{Mg}: \mathrm{N}$ (Aber et al. 1998). However, there is growing evidence that nitrate leaching is not simply proportional to the current level of $\mathrm{N}$ deposition. Soil $\mathrm{N}$ status, often coupled with land-use history, has been hypothesized to be more important than the current level of $\mathrm{N}$ deposition in determining rates of nitrate

Table 1. Different definitions of $\mathrm{N}$ saturation

\begin{tabular}{llcc}
\hline \hline \multicolumn{1}{c}{ Major criteria } & \multicolumn{1}{c}{ Definition } & Reference \\
\hline Plant growth & No further growth response of vegetation to an increase in the supply of N & $\begin{array}{c}\text { Nilsson (1986) } \\
\text { (re-cited from Gundersen 1991) }\end{array}$ \\
\hline Ecosystem N balance & An equivalence or excess of N losses from a system to N inputs to the system & Agren and Bosatta (1988) \\
\hline Inorganic N balance & $\begin{array}{l}\text { The availability of ammonium and nitrate in excess of total combined plant and } \\
\text { microbial nutritional demand }\end{array}$ & Aber et al. (1989) \\
\hline \multirow{2}{*}{ Alleviation of N limitation } & $\begin{array}{l}\text { A temporal series of changes in ecosystem processes in response to increased N } \\
\text { availability and the subsequent alleviation of N limitations on plant, microbial, and } \\
\text { abiotic soil processes }\end{array}$ & $\begin{array}{c}\text { Aber (1992) and Aber et al. } \\
\text { (1995) }\end{array}$ \\
\hline
\end{tabular}


Table 2. Major on- and off-site impacts of forest $\mathrm{N}$ saturation

\begin{tabular}{|c|c|c|c|}
\hline & Major effects & Symptoms & Major references \\
\hline \multirow{7}{*}{$\begin{array}{l}\text { On-site } \\
\text { impacts }\end{array}$} & Foliar nutrient responses & $\mathrm{N}$ excess, nutritional deficiency and imbalances & $\begin{array}{l}\text { Fenn et al. 1996, Magill et al. 1997, Boxman } \\
\text { et al. 1998, Elvir et al. } 2005\end{array}$ \\
\hline & $\begin{array}{l}\text { Changes in stress tolerance } \\
\text { of trees }\end{array}$ & Increased susceptibility to frost, droughts, pests, etc. & Nihlgård 1985, Schulze 1989 \\
\hline & $\begin{array}{l}\text { Changes in reproductive } \\
\text { efficiency of trees }\end{array}$ & Reduced reproductive efficiency & $\begin{array}{l}\text { Falkengren-Grerup and Eriksson 1990, Wedin } \\
\text { and Tilman 1996, Brunet et al. } 1998\end{array}$ \\
\hline & Tree mortality & Increased tree mortality and forest decline & $\begin{array}{l}\text { Nihlgård 1985, Schulze 1989, McNulty et al. } \\
1996\end{array}$ \\
\hline & Altered soil chemistry & $\begin{array}{l}\text { Acidification caused by nitrification and nitrate leaching, } \\
\text { base cation depletion, and increased inorganic } \mathrm{Al}\end{array}$ & $\begin{array}{l}\text { Kahl et al. 1993, Matzner and Murach 1995, } \\
\text { Gundersen et al. 1998b }\end{array}$ \\
\hline & $\begin{array}{l}\text { Disturbed biogeochemical } \\
\text { cycles }\end{array}$ & $\begin{array}{l}\text { Altered rates of soil organic matter decomposition and } \\
\mathrm{N} \text { cycle }\end{array}$ & $\begin{array}{l}\text { Fog 1988, Berg and Matzner 1997, Magill and } \\
\text { Aber 1998, Pregitzer et al. 2004, } 2008\end{array}$ \\
\hline & Effects on soil biota & Changes in patterns of mycorrhizal infection & Rühling and Tyler 1991, Boxman et al. 1998 \\
\hline \multirow{5}{*}{$\begin{array}{l}\text { Off-site } \\
\text { impacts }\end{array}$} & Stream water pollution & $\begin{array}{l}\text { Increases in nitrate leaching and export to downstream } \\
\text { waters }\end{array}$ & $\begin{array}{l}\text { Stoddard 1994, Dise and Wright 1995, Aber et } \\
\text { al. 2003, Driscoll et al. } 2003\end{array}$ \\
\hline & Effects on aquatic biota & $\begin{array}{l}\text { Increased mortality of fish and other sensitive species } \\
\text { from increased acidity and inorganic Al concentrations }\end{array}$ & $\begin{array}{l}\text { Hinga et al. 1991, Jaworski et al. 1997, Raba- } \\
\text { lais } 2002\end{array}$ \\
\hline & Effects on air quality & Increased production of photochemical oxidants & Dentener et al. 2006 \\
\hline & Effects on global warming & $\begin{array}{l}\text { Changes in formation of trace greenhouse gases }\left(\mathrm{N}_{2} \mathrm{O}\right. \\
\left.\& \mathrm{O}_{3}\right) \text { and aerosols }\end{array}$ & $\begin{array}{l}\text { Gundersen 1991, Tietema et al. 1991, Hall and } \\
\text { Matson 1999, Matson et al. } 2002\end{array}$ \\
\hline & $\begin{array}{l}\text { Indirect effects on greenhouse } \\
\text { gas exchange }\end{array}$ & Decreases in methane consumption in soils & Steudler et al. 1989 \\
\hline
\end{tabular}

leaching (Aber and Driscoll 1997, Gundersen et al. 1998b). Gundersen et al. (1998b) attributed the observed discrepancy between $\mathrm{N}$ deposition and nitrate leaching to the land-use history of the forest stands and further argued that nitrate leaching can be delayed for several years at sites with low levels of $\mathrm{N}$ stock, even under high levels of $\mathrm{N}$ deposition. The ratio of $\mathrm{C}$ to $\mathrm{N}$ in the forest floor has been proposed as a sensitive indicator of the site $\mathrm{N}$ status and $\mathrm{N}$ leaching potential (Dise et al. 1998, Gundersen et al. 1998a, Lovett et al. 2002, MacDonald et al. 2002, Gundersen et al. 2006). For example, in a compilation of regional data sets on $\mathrm{N}$ leaching from European forests, Gundersen et al. (2006) found that a forest floor $\mathrm{C} / \mathrm{N}$ ratio of 25 was the threshold for elevated nitrate leaching from coniferous forests under chronic $\mathrm{N}$ deposition.

Predicting the timing of $\mathrm{N}$ saturation is critical for the determination of critical loads of $\mathrm{N}$ for sensitive forest ecosystems (Aber 1992, Jefferies and Maron 1997). On the basis of nitrate leaching patterns, Dise and Wright (1995) proposed an N deposition 'input threshold' in the range of $10 \sim 25 \mathrm{~kg} \mathrm{~N} \mathrm{ha}{ }^{-1} \mathrm{yr}^{-1}$, above which noticeable $\mathrm{N}$ leaching appears in runoff. Gundersen et al. (2006) found elevated nitrate concentrations in stream waters draining European forests with chronic $\mathrm{N}$ deposition at the level of $8 \sim 10 \mathrm{~kg} \mathrm{~N} \mathrm{ha}^{-1}$ $\mathrm{yr}^{-1}$. As noted, however, nitrate leaching often lags far behind the initiation of forest $\mathrm{N}$ saturation. Thus, predicting ecosystem responses to enhanced $\mathrm{N}$ deposition requires a more complete understanding of the capacity and mechanisms of forest $\mathrm{N}$ retention.

\section{EFFECTS OF N DEPOSITION ON MICROBIAL-DETRITAL COMPLEXES IN THE FOREST FLOOR}

\section{$N$ Retention in the Forest Floor}

$\mathrm{N}$ retention in forests is largely determined by the competition for available $\mathrm{N}$ between plants, heterotrophic microbes, and nitrifiers, along with nonbiological $\mathrm{N}$ incorporation into soil organic matter (Johnson 1992). Early N saturation studies assumed that plant uptake was likely to be the primary sink for $\mathrm{N}$ either from atmospheric deposition or from fertilization (Aber et al. 1989), based on the hypothesis of forest $\mathrm{N}$ retention assuming increasing $\mathrm{N}$ leaching with increasing forest age (Vitousek and Reiners 1975). However, 
recent evidence suggests that the forest floor and mineral soil are often more important $\mathrm{N}$ sinks than forest vegetation (Emmet et al. 1998, Gundersen et al. 1998b, Tietema et al. 1998, Nadelhoffer et al. 1999b, 2004). In a cross-site comparison of $19{ }^{15} \mathrm{~N}$-tracer studies, Fenn et al. (1998) found a greater retention capacity in the soil pools than the vegetation, with $4-37 \%$ of the labeled $\mathrm{N}$ recovered in vegetation and $19 \sim 87 \%$ in soil. Nadelhoffer et al. (1999b) found similar results, indicating the significance of soils as the primary $\mathrm{N}$ sink in a synthesis of the results from ${ }^{15} \mathrm{~N}$-tracer studies conducted in six European and three North American forests. Their analysis found that less than $20 \%$ of ${ }^{15} \mathrm{~N}$ added for up to 3 years was recovered in tree biomass, while the remaining fractions were retained in the forest floor or mineral horizons. Stand age and understory vegetation might affect plant $\mathrm{N}$ uptake (Fenn et al. 1998). For example, understory vegetation played a more important role in $\mathrm{N}$ retention than overstory trees in some European forests (Buchman et al. 1996, Tietema et al. 1998).

Many ${ }^{15} \mathrm{~N}$-tracer experiments have shown that the soil organic horizons are a stronger sink than the mineral soil (Tietema et al. 1998, Nadelhoffer et al. 1999a, 2004). In some European forests, $10 \sim 15 \%$ of added ${ }^{15} \mathrm{~N}$ was retained in the mineral soil, while the organic horizons retained up to $45 \%$ of applied ${ }^{15} \mathrm{~N}$ (Tietema et al. 1998). Nadelhoffer et al. (1999a) also reported a higher retention capacity of the forest floor $(34 \sim 44 \%)$ than the mineral soil (15 $28 \%$ ) in two chronically N-fertilized forests. Based on the decreased efficiency of $\mathrm{N}$ retention in the forest floor with increasing $\mathrm{N}$ input, along with the absence of significant changes in the $\mathrm{N}$ retention efficiency of trees and mineral soil, Tietema et al. (1998) suggested that increased $\mathrm{N}$ leaching loss from $\mathrm{N}$-enriched forests might be a result of the saturation of microbial $\mathrm{N}$ immobilization capacity.

Although substantial amounts of $\mathrm{N}$ retained in forests appear to accumulate in the soil pools, there is very limited information about the processes and controls of microbial and abiotic $\mathrm{N}$ incorporation in the forest floor. Johnson (1992) argued that $\mathrm{N}$ incorporation into soil organic matter is in part nonbiological in nature, controlled by physicochemical properties and litter inputs from above-ground plants. In a laboratory incubation experiment using both sterilized and nonsterilized forest floor samples, Schimel and Firestone (1989) found that $20 \%$ of ${ }^{15} \mathrm{~N}$-labeled ammonium was abiotically incorporated in the forest floor samples. Although it has long been believed that microbial $\mathrm{N}$ assimilation plays a dominant role in the retention of $\mathrm{N}$ in soil organic pools (Sjöberg and Persson 1998, Tietema et al. 1998, Park et al. 2002), some recent studies ascribed rapid immobilization of nitrate in soil organic matter to abiotic transformation processes involving nitrate reduction by iron and reaction of nitrite with dissolved organic matter (Dail et al. 2001, Davidson et al. 2003). In a follow-up study, however, Colman et al. (2007) showed that abiotic $\mathrm{N}$ retention observed in the previous studies might be the result of iron inference with nitrate measurements and argued that abiotic $\mathrm{N}$ retention is an unlikely explanation for the high rates of nitrate retention observed in many forests under chronic $N$ deposition.

\section{Control on N Turnover in N-Enriched Forest Floors}

Heterotrophs, or heterotrophic microorganisms, have traditionally been regarded as the most effective short-term competitor for available N in soils (Jones and Richards 1977, Roswall 1982, Riha et al. 1986, Zak et al. 1990, Johnson 1992). When heterotrophs and plat roots compete for ammonium in N-limited systems, the heterotrophs may have an advantage due to higher substrate affinity (Roswall 1982, Verhagen et al. 1995). In contrast, nitrifiers have been regarded as weak competitors compared to heterotrophs or plants (Jones and Richards 1977, Roswall 1982, Riha et al. 1986). However, some recent studies have challenged this assumption. Stark and Hart (1997) found high rates of gross nitrification and microbial nitrate assimilation in 11 undisturbed forest soils, for which measurements of net nitrification would not have revealed any production or assimilation of nitrate. Johnson (1992) suggested that nitrification could be dominant under certain conditions such as chronic low-level $\mathrm{N}$ deposition or frequent fertilization with small doses of $\mathrm{N}$. Tietema (1998), however, found no significant gross microbial nitrate immobilization in forest floor samples collected along an $\mathrm{N}$ deposition gradient across Europe.

Nitrifiers seem to become more competitive if the ammonium supply is in excess of heterotrophic maintenance requirement and thus some other growth factors, such as $\mathrm{C}$, limit the growth of heterotrophs (Riha et al. 1986). The so-called 'carbon control' of microbial $\mathrm{N}$ assimilation has been shown in many field and laboratory incubation experiments (Jones and Richards 1977, Johnson and Edwards 1979, Reinertsen et al. 1984, Wheatley et al. 1991, Hart et al. 1994, Park et al. 2002 and 2006). In a laboratory incubation experiment, Hart et al. (1994) showed that large increases in nitrification at the later stages of incubation were related to an elevated ammonium supply in excess of heterotrophic demand, which was presumably limited by the decline of available $\mathrm{C}$ sources. Stark and Hart (1997) also related high nitrification rates to high ammonium availability relative to $\mathrm{C}$ availability.

In mineral soils the growth and activity of heterotrophic microorganisms appear to be primarily limited by the availability of $\mathrm{C}$ (Foster et al. 1980, Lynch 1982, McGill et al. 1986, Zak et al. 1990), whereas $\mathrm{N}$ limitation might be a more prevalent condition in $\mathrm{C}$-rich organic soils (Wardle 1992, Gallardo and Schlesinger 1994, Scheu and Schaefer 1998). However, significantly reduced rates of $\mathrm{N}$ retention in the forest floor under chronic $\mathrm{N}$ deposition have been 
shown in both field and laboratory manipulations of forest floor $\mathrm{C}$ sources, pointing to the possibility that $\mathrm{N}$ supply in excess of available $\mathrm{C}$ sources might be responsible for reduced microbial $\mathrm{N}$ immobilization in the N-enriched forest floor (Park et al. 2002, Park and Matzner 2006).

To elucidate unexpectedly high rates of $\mathrm{N}$ retention in soil organic pools, Aber et al. (1998) hypothesized that soil microbes could assimilate more added $\mathrm{N}$ if untapped $\mathrm{C}$ sources become available in response to an $\mathrm{N}$ surge. DOC in soil solution was proposed as the most probable candidate and a decrease in DOC concentration following $\mathrm{N}$ fertilization was predicted to signify microbial $\mathrm{N}$ assimilation in chronically $\mathrm{N}$-fertilized forests. Some $\mathrm{N}$ addition experiments have reported significant increases (up to $200 \sim 300 \%$ ) in dissolved organic nitrogen (DON) concentrations in forest floor leachates following field fertilization (Currie et al. 1996, McDowell et al. 1998) or laboratory incubation (Park et al. 2002). However, the possibility of DOC as a bio-available $\mathrm{C}$ pool in N-enriched soils was not corroborated in many $\mathrm{N}$ fertilization studies (Currie et al. 1996, Gundersen et al. 1998b, McDowell et al. 1998, 2004). McDowell et al. (1998) detected no significant change in the supply of DOC from decomposition of fresh litter, root exudation, and mycorrhizal fungi in response to the altered $\mathrm{N}$ status of fertilized forest floors under field conditions. Substantial amounts of DOC can also be produced from older litter or humified materials for a prolonged period without new C inputs (Park and Matzner 2003, Kalbitz et al. 2007). Aber et al. (1998) revised their original hypothesis and proposed that only mycorrhizal fungi can assimilate substantial amounts of added $\mathrm{N}$ without a high $\mathrm{C}$ cost, because they obtain $\mathrm{C}$ directly from their host plants. However, reduced growth of mycorrhizal fungi has repeatedly been observed in chronically N-deposited forests (Rühling and Tyler 1991, Boxman et al. 1998, Frey et al. 2004).

\section{IMPLICATIONS OF CHANGING C-N INTERACTIONS FOR FOREST C SEQUESTRATION}

Although forest floors store only 3 to $6 \%$ of the global $\mathrm{C}$ pool in the top $3 \mathrm{~m}$ of mineral soil, forest floor $\mathrm{C}$ pools can change in size relatively quickly in response to changes in environmental conditions as compared to the mineral soil (Currie et al. 2003). Thus, slight changes in forest floor $\mathrm{C}-\mathrm{N}$ interactions in response to chronic $\mathrm{N}$ deposition can have significant implications for $\mathrm{C}$ storage in organic horizons and $\mathrm{N}$ distribution among different forest compartments. In evaluating the contribution of $\mathrm{N}$ deposition to $\mathrm{C}$ sequestration in forests, it is crucial to understand how retained $\mathrm{N}$ in forests is distributed among forest compartments (Melillo 1996, Nadelhoffer 1999a). For example, Nadelhoffer et al. (1999b) obtained a much lower value $\left(0.25 \mathrm{Pg} \mathrm{C} \mathrm{yr}^{-1}\right)$ for terrestrial $\mathrm{C}$ sequestration attributed to $\mathrm{N}$ deposition than other reported estimates $(1.5 \sim 2.0$ $\mathrm{Pg} \mathrm{C} \mathrm{yr}{ }^{-1}$ ), because they assumed that most $\mathrm{N}$ retained in temperate forests accumulates in soil pools with lower $\mathrm{C} / \mathrm{N}$ rather than in the woody compartment, which has higher $\mathrm{C} / \mathrm{N}$ ratios.

Recent findings have allowed categorization of forest floor $\mathrm{N}$ retention mechanisms into three major pathways, each of which has different consequences for $\mathrm{C}$ sequestration and forest responses to climate change (Fig. 1). $\mathrm{N}$ availability has been proposed as a major constraint on plant biomass accumulation in response to rising atmospheric $\mathrm{CO}_{2}$ (Hungate et al. 2003, Reich et al. 2006) or climatic warming (Shaver et al. 2000), although the response of plant $\mathrm{C}$ accumulation to environmental changes is determined by a suite of controlling factors other than $\mathrm{N}$, including plant species and soil nutritional status. As depicted in pathway I of Fig. 1, increased inputs of $\mathrm{N}$ to forests with limited natural supply can initially enhance tree biomass accumulation per unit area through increased activity of the photosynthesizing enzyme RUBISCO (Högberg 2007). The terrestrial $C$ sink represents $15 \sim 30 \%$ of annual global emission of $\mathrm{C}$ from anthropogenic sources and evidence for biomass $\mathrm{C}$ accumulation in boreal and temperate forests has lately been provided by satellite observations or plot-level measurements of ecosystem $C$ exchange (Myneni et al. 2001, Magnani et al. 2007). These results corroborate the previous findings suggesting that increasing $\mathrm{N}$ deposition over large forested regions can stimulate tree growth and this $\mathrm{N}$-stimulated $\mathrm{C}$ storage might account for a substantial portion of the missing $C$ in temperate regions (Kauppi et al. 1992, Schimel 1995, Melillo 1996, Townsend et al. 1996). A recent analysis of C balance measurements across a network of forests in Europe and the USA along a range of $\mathrm{N}$ deposition levels showed that forest net $\mathrm{C}$ sequestration was primarily driven by $\mathrm{N}$ deposition when the confounding effects of natural disturbances had been removed (Mag. nani et al. 2007). Magnani et al. (2007) ascribed N-induced increases in forest $\mathrm{C}$ storage to the positive growth response of plants to moderate levels of $\mathrm{N}$ deposition, assuming that plants outcompete soil microbes for excess $\mathrm{N}$ supply.

In $\mathrm{N}$-saturated forests, $\mathrm{C}$ loss from forests can equal or outweigh $\mathrm{C}$ gain (pathway $\mathrm{II}$ in Fig. 1). According to the $\mathrm{N}$ saturation hypothesis summarized in the previous section, the fertilization effects of $\mathrm{N}$ on forest growth are temporary, as growth is constrained by the adverse effects of $\mathrm{N}$ saturation or limiting factors other than $\mathrm{N}$. Asner et al. (1997) used the concept 'decoupling of $\mathrm{C}$ and $\mathrm{N}$ cycles' to describe the reversal of earlier $\mathrm{N}$-stimulated increases in $\mathrm{C}$ sequestration by a leveling-off or decline when $\mathrm{N}$ limitation is alleviated and further $\mathrm{C}$ storage is offset by $\mathrm{C}$ loss from negative effects of $\mathrm{N}$ saturation. The apparent discrepancy between the predicted decreases in $\mathrm{N}$-induced $\mathrm{C}$ storage in $\mathrm{N}$-saturated forests (sensu As- 


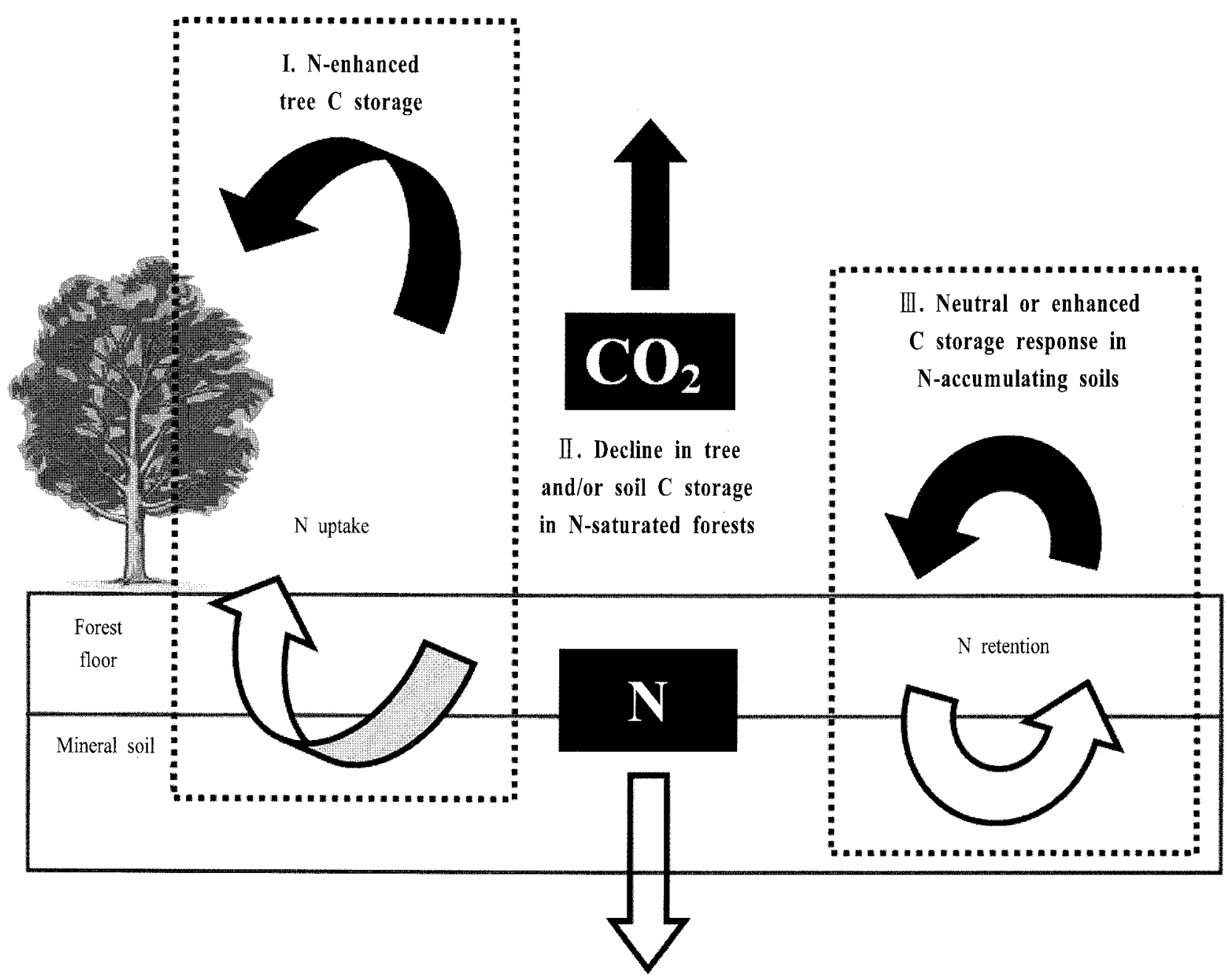

$\mathrm{N}$ leaching

Fig. 1. Schematic diagram of three different pathways of $\mathrm{N}$ retention in the forest floor and their implications for forest $\mathrm{C}$ sequestration.

ner et al. 1997) and the observed relatively high plant $\mathrm{C}$ accumulation in European forests under chronically elevated $\mathrm{N}$ deposition (de Vries et al. 2006, Maganani et al. 2007) raises a question as to how much and for how long $\mathrm{N}$ must be added to forests to induce the shift from $\mathrm{N}$-induced $\mathrm{C}$ storage to $\mathrm{C}-\mathrm{N}$ decoupling.

Somewhat contrasting results with regard to $\mathrm{N}$-induced $\mathrm{C}$ storage have led to the exploration of other possible pathways for $\mathrm{N}$ retention in forest soils under ambient levels of $\mathrm{N}$ deposition. Abiotic $\mathrm{N}$ immobilization in forest soils, which has been proposed by some researchers as the primary mechanism allowing high $\mathrm{N}$ retention in response to $\mathrm{N}$ fertilization (Dail et al. 2001, Davidson et al. 2003), represents one mechanism in which increased $\mathrm{N}$ deposition does not have clear effects on tree $\mathrm{C}$ accumulation, but $\mathrm{N}$ incorporated in the forest floor or mineral soil exerts positive or neutral influences on soil $\mathrm{C}$ sequestration (pathway III in Fig. 1). When $\mathrm{N}$ is abiotically incorporated in the soil, bypassing microbial or plat uptake, it will only lower soil $\mathrm{C} / \mathrm{N}$ ratios without noticeable plant or soil $\mathrm{C}$ storage (de Vries et al. 2006).

The third pathway can also take another route if organic matter decomposition slows down in $\mathrm{N}$-enriched soils, resulting in soil $\mathrm{C}$ accumulation (Magill and Aber 1998, Michel and Matzner 2002, Waldrop et al. 2004, Pregitzer et al. 2008). Over the past couple of decades there have been numerous reports on soil organic matter accumulation caused by reduced organic matter decomposition in N-enriched forests (e.g., Nohrstedt et al. 1989, Smolander et al. 1994, Magill and Aber 1998, Pregitzer et al. 2008). In a long-term $\mathrm{N}$ fertilization experiment, Magill and Aber (1998) found a substantial reduction in the rate of litter decomposition in N-fertilized plots. After a decade of experimental $\mathrm{N}$ additions to four different hardwood forests in Michigan, Pregitzer et al. (2008) also found significant increases in surface soil $\mathrm{C}\left(690 \mathrm{~g} \mathrm{C} \mathrm{m}^{-2}\right)$ compared to the woody biomass $\mathrm{C}$ increment of $500 \mathrm{~g} \mathrm{C} \mathrm{m}^{-2}$. They ascribed the in- 
creased $\mathrm{C}$ storage at or near the soil surface to reduced decomposition of litter, as revealed by reductions in soil respiration (Burton et al. 2004) and lignolytic enzyme activities (DeForest et al. 2004). In a laboratory incubation experiment using forest floor (Oa) samples with different $\mathrm{C} / \mathrm{N}$ ratios, Michel and Matzner (2002) also showed decreasing soil respiration with decreasing $\mathrm{C} / \mathrm{N}$ ratios and suggested that chronic $\mathrm{N}$ deposition can increase $\mathrm{C}$ accumulation in forest floors through reduction in decomposition rates in later stages of litter decomposition. Forest floor $\mathrm{C}$ accumulation from reduced decomposition rates has significant implications for global $\mathrm{C}$ cycling in that suppressed humus decay can induce a negative feedback to the rising atmospheric $\mathrm{CO}_{2}$ concentration due to lowered $\mathrm{CO}_{2}$ emissions from soils, although $\mathrm{N}$ incorporated in more slowly decaying organic matter with lower $\mathrm{C} / \mathrm{N}$ ratios might make a relatively small, direct contribution to forest $\mathrm{C}$ sequestration.

\section{SUMMARY AND FUTURE RESEARCH NEEDS}

Chronic atmospheric $\mathrm{N}$ deposition was originally hypothesized to lead to $\mathrm{N}$ saturation of forest ecosystems along successional stages. Forest $\mathrm{N}$ saturation has been associated with long-term alleviation of $\mathrm{N}$ limitation on biological function and a subsequent decrease in $\mathrm{N}$ retention capacity of forests. Over the last couple of decades, however, numerous studies have shown surprisingly high rates of $\mathrm{N}$ retention, particularly in the forest floor. $\mathrm{N}$ retention in the forest floor has been explained by the competitive balance between tree roots, soil heterotrophs, and nitrifiers, which is in turn determined by the relative availability of $\mathrm{C}$ to $\mathrm{N}$ resources. To elucidate high rates of $\mathrm{N}$ retention in $\mathrm{N}$-enriched, $\mathrm{C}$-limited forest soils, abiotic $\mathrm{N}$ immobilization and mycorrhizal assimilation have been proposed as the alternative hypotheses. The fate of $\mathrm{N}$ in the forest floor has significant implications for forest $\mathrm{C}$ sequestration along three different pathways: $\mathrm{N}$-induced increases in tree $\mathrm{C}$ accumulation, $\mathrm{C}$ loss amounting to or surpassing $\mathrm{C}$ gain in $\mathrm{N}$-saturated, declining forests, and no change or $\mathrm{C}$ gain in $\mathrm{N}$-accumulating soils via abiotic retention or hampered organic matter decomposition. At forests across mid-to high-latitude regions, forest floor $\mathrm{N}$ retention under ambientlevel $\mathrm{N}$ deposition could be explained by three different pathways either in isolation or in combination, depending on the initial forest $\mathrm{N}$ status and transitional phases from $\mathrm{N}$ limitation to saturation.

Many questions remain to be answered with regard to $\mathrm{N}$ retention mechanisms in the forest floor under chronic $\mathrm{N}$ deposition. First, are heterotrophic microorganisms in $\mathrm{N}$-enriched forest soils primarily limited by available C? Second, can mycorrhizal fungi play an important role in the assimilation of excess $\mathrm{N}$ in C-limited soils? If so, how can we explain decreased activity of mycorrhizal fungi in $\mathrm{N}$-enriched forest soils as observed in many $\mathrm{N}$ addition experiments? Third, how can we quantify the relative importance of abiotic retention vs. mycorrhizal assimilation in retaining excess $\mathrm{N}$ in response to years of $\mathrm{N}$ fertilization or chronic $\mathrm{N}$ deposition. To better understand the relationship between the fate of $\mathrm{N}$ in the forest floor and $\mathrm{C}$ sequestration either in tree biomass or soils, more research effort should be paid to 'realistic' long-term monitoring studies focusing on $\mathrm{C}$ sequestration responses to a wide range of ambient-level atmospheric $\mathrm{N}$ deposition. To determine when $\mathrm{N}$-induced tree $\mathrm{C}$ storage shifts to ' $\mathrm{C}-\mathrm{N}$ decoupling' with two different consequences for $\mathrm{C}$ sequestration, alterations of forest floor $\mathrm{C}-\mathrm{N}$ interactions and their linkages with $\mathrm{C}$ sequestration need to be more thoroughly compared in different types of forests across a range of levels of $\mathrm{N}$ deposition and soil $\mathrm{N}$ status.

\section{ACKNOWLEDGMENTS}

This study was supported by Korea Forest Service research grant 'Forest Science \& Technology Projects' (Project No. S210808L010 1004 'Innovative Forest Disasters R\&D Center'). I thank three reviewers for their helpful comments and suggestions on the earlier draft of the manuscript.

\section{LITERATURE CITED}

Aber JD. 1992. Nitrogen cycling and nitrogen saturation in temperate forest ecosystems. TREE 7: 220-224.

Aber JD, Driscoll CT. 1997. Effects of land use, climate variation, and $\mathrm{N}$ deposition on $\mathrm{N}$ cycling and $\mathrm{C}$ storage in northern hardwood forests. Global Biogeochem Cy 11: 639-648.

Aber JD, Goodale CL, Ollinger SV, Smith ML, Magill AH, Martin ME, Hallett RA, Stoddard JL. 2003. Is nitrogen deposition altering the nitrogen status of northeastern forests? BioScience 53: 375 388.

Aber JD, McDowell W, Nadelhoffer K, Magil A, Berntson G, Kamakea M, McNulty S, Currie W, Rustad L, Fernandez I. 1998. Nitrogen saturation in temperate forest ecosystems: hypothesis revisited. BioScience 48: 921-934.

Aber JD, Nadelhoffer KJ, Steudler P, Mellilo JM. 1989. Nitrogen saturation in northern forest ecosystems. BioScience 39: 378-386.

Ågren GI, Bosatta E. 1988. Nitrogen saturation of terrestrial ecosystems. Environ Pollut 54: 185-197.

Asner GP, Seastedt TR, Townsend AR. 1997. The decoupling of terrestrial carbon and nitrogen cycles. BioScience 47: 226-234.

Berg B, Matzner E. 1997. Effect of $\mathrm{N}$ deposition on decomposition of plant litter and soil organic matter in forest systems. Environ Rev 5: $1-25$.

Boxman AW, Blanck K, Branrud TE, Emmet BA, Gundersen P, Hogervorst RF, Kjønaas OJ, Persson H, Timmermann V. 1998. Vegetation and soil biota response to experimentally-changed nitrogen inputs in coniferous forest ecosystems of the NITREX project. Forest Ecol Manag 101: 65-79. 
Brunet J, Diekmann M, Falkengren-Grerup U. 1998. Effects of nitrogen deposition on field layer vegetation in south Swedish oak forests. Environ Pollut 102, S1: 35-40.

Buchmann N, Gebauer G, Schulze ED. 1996. Partitioning of ${ }^{15} \mathrm{~N}$-labeled ammonium and nitrate among soil, litter, below- and aboveground biomass of trees and understory in a 15-year-old Picea abies plantation. Biogeochemistry 33: 1-23.

Burton AJ, Pregitzer KS, Crawford JN, Zogg GP, Zak DR. 2004. Chronic $\mathrm{NO}_{3}$ additions reduce soil respiration in northern hardwood forests. Global Change Biol 10: 1080-1091.

Colman BP, Fierer N, Schimel JP. 2007. Abiotic nitrate incorporation in soil: is it real? Biogeochemistry 84: 161-169.

Currie WS, Aber JD, McDowell WH, Boone RD, Magill AH. 1996. Vertical transport of dissolved organic $\mathrm{C}$ and $\mathrm{N}$ under long-term $\mathrm{N}$ amendments in pine and hardwood forests. Biogeochemistry 35 : 471-505.

Currie WS, Nadelhoffer KJ, Aber JD. 1999. Soil detrital processes controlling the movement of ${ }^{15} \mathrm{~N}$ tracers to forest vegetation. Ecol Appl 9: 87-102.

Currie WS, Nadelhoffer KJ. 1999. Dynamic redistribution of isotopically labeled cohorts of nitrogen inputs in two temperate forests. Ecosystems 2: 4-18.

Currie WS, Yanai RD, Piatek KB, Prescott CE, Goodale CL. 2003. Processes affecting carbon storage in the forest floor and in downed woody debris. In The Potential of U.S. Forest Soils to Sequester Carbon and Mitigate the Greenhouse Effect (Kimble JM, Heath LS, Birdsey RA, Lal R, eds). CRC Press, Boca Raton, pp 135-157.

Dail DB, Davidson EA, Chorover J. 2001. Rapid abiotic transformation of nitrate in an acid forest soil. Biogeochemistry 54: 131-146.

Davidson EA, Chorover J, Dail DB. 2003. A mechanism of abiotic immobilization of nitrate in forest ecosystems: the ferrous wheel hypothesis. Global Change Biol 9: 228-236.

DeForest J, Zak DR, Pregitzer KS, Burton AJ. 2004. Atmospheric nitrate deposition, microbial community composition, and enzyme activity in northern hardwood forests. Soil Sci Soc Am J 68: 132-138.

Dentener F, Stevenson D, Ellingsen K. et al. 2006. The global atmospheric environment for the next generation. Environ Sci Technol 40: $3586-3594$

de Vries W, Reinds GJ, Gundersen P, Sterba H. 2006. The impact of nitrogen deposition on carbon sequestration in European forests and forest soils. Globla Change Biol 12: 1151-1173.

Dise NB, Matzner E, Forsius M. 1998. Evaluation of organic horizon $\mathrm{C}: \mathrm{N}$ ratio as an indicator of nitrate leaching in conifer forests across Europe. Environ Pollut 102: 435-456.

Dise NB, Wright RF. 1995. Nitrogen leaching from European forests in relation to nitrogen deposition. Forest Ecol Manag 71: 153-161.

Driscoll CT, Whitall D, Aber J, Boyer E, Castro M, Cronan C, Goodale CL, Groffman P, Hopkinson C, Lambert K, Lawrence G, Ollinger S. 2003. Nitrogen pollution in the northeastern United States: sources, effects, and management options. BioScience 53 : 357-374.

Elvir JA, Rustad L, Wiersma GB, Fernandez IJ, White AS, White GJ 2005. Eleven-year response of foliar chemistry to chronic nitrogen and sulfur additions at the Bear Brook Watershed in Maine. Can J Forest Res 35: 1402-1410.

Emmett BA, Boxman D, Bredemeier M, Gundersen PG, Kjønaas OJ, Moldan F, Schleppi P, Tietema A, Wright RF. 1998. Predicting the effects of atmospheric nitrogen deposition in conifer stands: Evidence from the NITREX ecosystem-scale experiments. Ecosystems 1: 352-360.

Falkengren-Grerup U, Eriksson H. 1990. Changes in soil, vegetation and forest yield between 1947 and 1988 in beech and oak sites of southern Sweden. Forest Ecol Manag 38: 37-53.

Fenn ME, Poth MA, Aber JD, Baron JS, Bormann BT, Johnson DW, Lemly AD, McNulty SG, Ryan DF, Stottlemyer R. 1998. Nitrogen excess in North American ecosystems: Predisposing factors, ecosystem responses, and management strategies. Ecol Appl 8: 706733.

Fenn ME, Poth MA, Johnson DW. 1996. Evidence for nitrogen saturation in the San Bernardino Mountains in southern California. Forest Ecol Manag 82: 211-230.

Fog K. 1988. The effect of added nitrogen on the rate of decomposition of organic matter. Biol Rev 63: 433-462.

Foster NW, Beauchamp EG, Corke CT. 1980. Microbial activity in a Pinus banksiana Lamb. forest floor amended with nitrogen and carbon. Can J Soil Sci 60: 199-209.

Frey SD, Knorr M, Parrent JL, Simpson RT. 2004. Chronic nitrogen enrichment affects the structure and function of the soil microbial community in temperate hardwood and pine forests. Forest Ecol Manag 196: 159-171.

Gallardo A, Schlesinger WH. 1994. Factors limiting microbial biomass in the mineral soil and forest floor of a warm-temperate forest. Soil Biol Biochem 26: 1409-1415.

Galloway JN, Schlesinger WH, Levy H, Michaels A, Schnoor JL. 1995. Nitrogen fixation: anthropogenic enhancement-environmental response. Global Biogeochem Cy 9: 235-252.

Galloway JN, Townsend AR, Erisman JW, Bekunda M, Cai Z, Freney JR, Martinelli LA, Seitzinger SP, Sutton MA. 2008. Transformation of the nitrogen cycle: recent trends, questions, and potential solutions. Science 320: 889-892.

Giles J. 2005. Nitrogen study fertilizes fears of pollution. Nature 433: 791.

Gundersen P. 1991. Nitrogen deposition and the forest nitrogen cycle: role of denitrification. Forest Ecol Manag 44: 15-28.

Gundersen P, Callesen I, de Vries W. 1998a. Nitrate leaching in forest ecosystems is related to forest floor $\mathrm{C} / \mathrm{N}$ ratios. Environ Pollut 102: $403-407$.

Gundersen P, Emmett BA, Kjonaas OJ, Koopmans CJ, Tietema A. 1998b. Impact of nitrogen deposition on nitrogen cycling in forests: a synthesis of NITREX data. Forest Ecol Manag 101: 37-55.

Gundersen P, Schmidt IK, Raulund-Rasmussen K. 2006. Leaching of nitrate from temperate forests - Effects of air pollution and forest management. Environ Rev 14: 1-57.

Hall SJ, Matson PA. 1999. Nitrogen oxide emissions after nitrogen additions in tropical forests. Nature 400: 152-155.

Hart SC, Nason GE, Myrold DD, Perry DA. 1994. Dynamics of gross nitrogen transformations in an old-growth forest: the carbon connection. Ecology 75: 880-891. 
Hinga KR, Keller AA, Oviatt CA. 1991. Atmospheric deposition and nitrogen inputs to coastal waters. Ambio 20: 256-260.

Högberg P. 2007. Nitrogen impacts on forest carbon. Nature 447: 781-782.

Hungate BA, Dukes JS, Shaw MR, Luo Y, Field CB. 2003. Nitrogen and climate change. Science 302: 1512-1513.

Jaworski NA, Howarth RW, Hetling LJ. 1997. Atmospheric deposition of nitrogen oxides onto the landscape contributes to coastal eutrophication in the northeast United States. Environ Sci Technol 31: 1995-2004.

Jefferies RL, Maron JL. 1997. The embarrassment of riches: atmospheric deposition of nitrogen and community and ecosystem processes. TREE 12: 74-78.

Johnson DW, Edwards NT. 1979. The effects of stem girdling on biogeochemical cycles within a mixed deciduous forest in eastern Tennessee. II. Soil nitrogen mineralization and nitrification rates. Oecologia 40: 259-271.

Jones JM, Richards BN. 1977. Effect of reforestation on turnover of ${ }^{15} \mathrm{~N}$-labelled nitrate and ammonium in relation to changes in soil microflora. Soil Biol Biochem 9: 383-392.

Kahl JS, Norton SA, Fernandez IJ, Nadelhoffer KJ, Driscoll CT, Aber JD. 1993. Experimental inducement of nitrogen saturation at the watershed scale. Environ Sci Technol 27: 565-568.

Kalbitz K, Meyer A, Yang R, Gerstberger P. 2008. Response of dissolved organic matter in the forest floor to long-term manipulation of litter and throughfall inputs. Biogeochemistry 86: 301-318.

Kauppi PE, Mielikäinen K, Kuusela K. 1992. Biomass and carbon budget of European forests, 1971 to 1990. Science 256: 70-74.

Lovett GM, Weathers KC, Arthur MA. 2002. Control of nitrogen loss from forested watersheds by soil carbon: nitrogen ratio and tree species composition. Ecosystems 5: 712-718.

Lynch JM. 1982. Limits to microbial growth in soil. J Gen Microbiol 128: $405-410$.

MacDonald JA, Dise NB, Matzner E, Armbruster M, Gundersen P, Forsius M. 2002. Nitrogen input together with ecosystem nitrogen enrichment predict nitrate leaching from European forests. Global Change Biol 8: 1028-1033.

Magill AH, Aber JD. 1998. Long-term effects of experimental nitrogen additions on foliar litter decay and humus formation in forest ecosystems. Plant Soil 203: 301-311.

Magill AH, Aber JD, Hendricks J, Bowden RD, Melillo JM, Steudler PA. 1997. Biogeochemical response of forest ecosystems to simulated chronic nitrogen deposition. Ecol Appl 7: 402-415.

Magill AH, Downs MR, Nadelhoffer KJ, Hallett RA, Aber JD. 1996. Forest ecosystem response to four years of chronic nitrate and sulfate additions at Bear Brooks Watershed, Maine, USA. Forest Ecol Manag 84: 29-37.

Magnani F, Mencuecini M, Borghetti M, et al. 2007. The human footprint in the carbon cycle of temperate and boreal forests. Nature 447: 848-852.

Matson P, Lohse KA, Hall SJ. 2002. The globalization of nitrogen deposition: consequences for terrestrial ecosystems. Ambio 31: 113-119.

Matzner E, Murach D. 1995. Soil changes induced by air pollutant deposition and their implication for forests in Central Europe.
Water Air Soil Pollut. 85: 63-76.

McDowell WH, Currie WS, Aber JD, Yano Y. 1998. Effects of chronic nitrogen amendments on production of dissolved organic carbon and nitrogen in forest soils. Water Air Soil Pollut 105: 175-182.

McDowell WH, Magill AH, Aitkenhead-Peterson JA, Aber JD, Merriam JL Kaushal SS. 2004. Effects of chronic nitrogen amendment on dissolved organic matter and inorganic nitrogen in soil solution. Forest Ecol Manag 196: 29-41.

McGill WB, Cannon KR, Robertson JA, Cook FD. 1986. Dynamics of soil microbial biomass and water-soluble organic $\mathrm{C}$ in Breton $\mathrm{L}$ after 50 years of cropping to two rotations. Can J Soil Sci 66 : $1-19$.

McNulty SG, Aber JD, Newman SD. 1996. Nitrogen saturation in a high elevation spruce-fir stand. Forest Ecol Manag 84: 109-121.

Melillo JM. 1996. Carbon and nitrogen interactions in the terrestrial biosphere: anthropogenic effects. In Global Change and Terrestrial Ecosystems (Walker B, Steffen W, eds). Cambridge University Press, Cambridge, pp 431-450.

Michel K, Matzner E. 2002. Nitrogen content of forest floor Oa layers affects carbon pathways and nitrogen mineralization. Soil Biol Biochem 34: 1087-1813.

Myneni RB, Dong J, Tucker CJ, Kaufmann RK, Kauppi PE, Liski J, Zhou L, Alexeyev V. 2001. A large carbon sink in the woody biomass of Northern forests. PNAS 98: 14784-14789.

Nadelhoffer KJ, Colman BP, Currie WS, Magill A, Aber JD. 2004. Decadal-scale fates of ${ }^{15} \mathrm{~N}$ tracers added to oak and pine stands under ambient and elevated $\mathrm{N}$ inputs at the Havard Forest (USA). Forest Ecol Manag 196: 89-107.

Nadelhoffer KJ, Downs MR, Fry B. 1999a. Sinks for ${ }^{15} \mathrm{~N}$-enriched additions to an oak forest and a red pine plantation. Ecol Appl 9: $72-86$.

Nadelhoffer, KJ, Emmett BA, Gundersen P, Kjønaas OJ, Koopmans CJ, Schleppi P, Tietema A, Wright RF. 1999b. Nitrogen deposition makes a minor contribution to carbon sequestration in temperate forests. Nature 398: 145-148.

Nihlgård B. 1985. The ammonium hypothesis - an additional explanation to the forest dieback in Europe. Ambio 14: 2-8.

Nilsson J, ed. 1986. Critical Loads for Sulfur and Nitrogen, Miljørapport 11. Nordic Council of Ministers, Copenhagen.

Nohrstedt HÖ, Arnebrant K, Bååth E, Söderström B. 1989. Changes in carbon content, respiration rate, ATP content, and microbial biomass in nitrogen-fertilized pine forest soils in Sweden. Can J Forest Res 19: 323-328.

Park JH, Kalbitz K, Matzner E. 2002. Resource control on the production of dissolved organic carbon and nitrogen in a deciduous forest floor. Soil Biol Biochem 34: 813-822.

Park JH, Matzner E. 2003. Controls on the release of dissolved organic carbon and nitrogen from a deciduous forest floor investigated by manipulations of aboveground litter inputs and water flux. Biogeochemistry $66: 265-286$.

Park JH, Matzner E. 2006. Detrital control on the release of dissolved organic nitrogen (DON) and dissolved inorganic nitrogen (DIN) from the forest floor under chronic $\mathrm{N}$ deposition. Environ Pollut 143: $178-185$

Peterjohn WT, Adams MB, Giliam FS. 1996. Symptoms of nitrogen 
saturation in two central Appalachian hardwood forest ecosystems. Biogeochemistry 35: 507-522.

Pregitzer KS, Burton AJ, Zak DR, Talhelm AF. 2008. Simulated chronic nitrogen deposition increases carbon storage in northern temperate forests. Global Change Biol 14: 142-153.

Pregitzer KS, Zak DR, Burton AJ, Ashby A, MacDonald NW. 2004. Chronic nitrate additions dramatically increase the export of carbon and nitrogen from northern hardwood ecosystems. Biogeochemistry 68: 179-197.

Rabalais NN. 2002. Nitrogen in aquatic ecosystems. Ambio 31: 102112.

Reich PB, Hobbie SE, Lee T, Ellsworth DS, West JB, Tilman D, Knops JMH, Naeem S, Trost J. 2006. Nitrogen limitation constrains sustainability of ecosystem response to $\mathrm{CO}_{2}$. Nature 440 : 922-925.

Reinertsen SA, Elliott LF, Cochran VL, Campbell GS. 1984. Role of available carbon and nitrogen in determining the rate of wheat straw decomposition. Soil Biol Biochem 16: 459-464.

Riha SJ, Campbell GS, Wolfe J. 1986. A model of competition for ammonium among heterotrophs, nitrifiers, and roots. Soil Sci Soc Am J 50: 1463-1466.

Rosswall T. 1982. Microbiological regulation of the biogeochemical nitrogen cycle. Plant and Soil 67: 15-34.

Rühling $\AA$, Tyler G. 1991. Effects of stimulated nitrogen deposition to the forest floor on the macrofungal flora of a beech forest. Ambio 20: $261-263$

Scheu S, Schaefer M. 1998. Bottom-up control of the soil macrofauna community in a beechwood on limestone: manipulation of food resources. Ecology 79: 1573-1585.

Schulze ED. 1989. Air pollution and forest decline in a spruce forest. Science 244: 776-783.

Schimel DS. 1995. Terrestrial ecosystems and the carbon cycle. Global Change Biol 1: 77-91.

Schimel JP, Firestone MK. 1989. Inorganic N incorporation by coniferous forest floor material. Soil Biol Biochem 21: 41-46.

Shaver GR, Canadell J, Chapin FS, Gurevitch J, Harte J, Henry G, Ineson P, Jonasson S, Melillo J, Pitelka L, Rustad L. 2000. Global warming and terrestrial ecosystems: a conceptual framework for analysis. BioScience 50: 871-882.

Sjöberg RM, Persson T. 1998. Turnover of carbon and nitrogen in coniferous forest soils of different $\mathrm{N}$-status and under different ${ }^{15} \mathrm{NH}_{4}$ N application rate. Environ Pollut 102, S1: 385-393.

Smolander A, Kurka A, Kitunen V, Mälkönen E. 1994. Microbial biomass $\mathrm{C}$ and $\mathrm{N}$, and respiratory activity in soil of repeatedly limed and $\mathrm{N}$ - and P-fertilized Norway spruce stands. Soil Biol Biochem 26: $957-962$

Stark JM, Hart SC. 1997. High rates of nitrification and nitrate turnover in undisturbed coniferous forests. Nature 385: 61-64.

Steudler PA, Bowden RD, Melillo JM, Aber JD. 1989. Influence of nitrogen fertilization on methane uptake in temperate forest soils. Nature 341: 314-316.

Stoddard JL. 1994. Long-term changes in watershed retention of nit- rogen: its causes and aquatic consequences. In Environmental Chemistry of Lakes and Reservoirs (Baker LA, ed), Advances in Chemistry Series No. 237, Ame. Che. Soc., Washington, D.C., pp 223-284.

Tamm CO, Aronsson A, Popovic B. 1995. Nitrogen saturation in a long-term forest experiment with annual additions of nitrogen. Water Air Soil Pollut 85: 1683-1688.

Tietema A. 1998. Microbial carbon and nitrogen dynamics in coniferous forest floor material collected along a European nitrogen deposition gradient. Forest Ecol Manag 101: 29-36.

Tietema A, Bouten W, Wartenbergh PE. 1991. Nitrous oxide dynamics in an oak-beech forest ecosystem in the Netherlands. Forest Ecol Manag 44: 53-61.

Tietema A, Emmet BA, Gundersen P, Kjonaas OJ, Koopmans CJ. 1998. The fate of ${ }^{15} \mathrm{~N}$-labelled nitrogen deposition in coniferous forest ecosystems. Forest Ecol Manag 101: 19-27.

Townsend AR, Braswell BH, Holland EA, Penner JE. 1996. Spatial and temporal patterns in terrestrial carbon storage due to deposition of fossil fuel nitrogen. Ecol Appl 6: 806-814.

Verhagen FJM, Laanbroek HJ, Woldendorp JW. 1995. Competition for ammonium between plant roots and nitrifying and heterotrophic bacteria and the effects of protozoan grazing. Plant Soil 170: 241-250.

Vitousek PM, Aber JD, Howarth RW, Likens GE, Matson PA, Schindler DW, Schlesinger WH, Tilman DG. 1997. Human alteration of the global nitrogen cycle. Ecol Appl 7: 737-750.

Vitousek PM, Howarth RW. 1991. Nitrogen limitation on land and in the sea: How can it occur? Biogeochemistry 13: 87-115.

Vitousek PM, Reiners WA. 1975. Ecosystem succession and nutrient retention: a hypothesis. BioScience 25: 376-381.

Waldrop MP, Zak DR, Sinsabaugh RL, Gallo M, Lauber C. 2004. Nitrogen deposition modifies soil carbon storage through changes in microbial enzymatic activity. Ecol Appl 14: 1172-1177.

Wardle DA. 1992. A comparative assessment of factors which influence microbial biomass carbon and nitrogen levels in soil. Biol Rev 67 : 321-358.

Wedin DA, Tilman D. 1996. Influence of nitrogen loading and species composition on the carbon balance of grasslands. Science 274 : $1720-1723$.

Wheatley RE, Griffiths BS, Ritz K. 1991. Variations in the rates of nitrification and denitrification during the growth of potatoes ( $\mathrm{So}$ lanum tuberosum L.) in soil with different carbon inputs and the effect of these inputs on soil nitrogen and plant yield. Biol Fertil Soils 11: 157-162.

Wright RF, Rasmussen L. 1998. Introduction to the NITREX and EXMAN projects. Forest Ecol Manag 101: 1-7.

Wright RF, van Breemen N. 1995. The NITREX project: an introduction. Forest Ecol Manag 71: 1-5.

Zak DR, Grigal DF, Gleeson S, Tilman D. 1990. Carbon and nitrogen cycling during old-field succession: constraints on plant and microbial biomass. Biogeochemistry 11: 111-129.

(Received July 31, 2008; Accepted August 11, 2008) 